\title{
Research on Roma health and access to healthcare: state of the art and future challenges
}

\author{
Maria Eva Földes • Alina Covaci
}

Published online: 5 October 2011

(C) The Author(s) 2011. This article is published with open access at Springerlink.com

\section{Introduction}

Health inequalities experienced by Roma people living in Europe presents a persisting challenge for health research and practice. Available literature on Roma and health agrees that: (1) Roma people suffer from poorer health and unhealthier living conditions compared to majority populations, (2) better data are needed to explain the Roma health gap and design better interventions to reduce this gap and (3) the poor health of Roma is closely linked to the social determinants of health. This editorial discusses the lessons to be learnt from recent research findings and outlines a number of challenges in exploring and addressing the various mechanisms that contribute to the health gap between Roma and majority populations.

\section{The Roma health gap: understanding the underlying mechanisms}

During recent years we have been witnessing two notable developments in research on Roma health. First, the focus has been gradually extended from communicable diseases, child health and genetic disorders that constituted the dominant topics a decade ago (Hajioff and McKee 2000;

\section{E. Földes ( $\square)$}

Faculty of Law, Department of European and International

Law and Tilburg Law and Economics Centre (TILEC),

Tilburg University, PO Box 90153, 5000, LE, Tilburg,

The Netherlands

e-mail: E.M.Foldes@uvt.nl

\section{A. Covaci}

Roma Health Project, Open Society Foundations, 1051 Budapest, Hungary
Zeman et al. 2003) to non-communicable diseases, chronic illnesses and associated risk factors (Mladovsky 2007; Masseria et al. 2010). Second, research has moved from predominantly descriptive studies on Roma health status towards more analytical studies exploring the factors that determine the health inequalities faced by Roma.

Recent evidence shows that Roma people experience specific health inequalities that cannot be traced back fully to socioeconomic factors (Masseria et al. 2010; Paulik et al. 2011; Kolarcik et al. 2009, 2010; Rosicova et al. 2011). The importance of assessing the explanatory power of socioeconomic status versus other factors has been highlighted in the context of exploring the pathways leading to ethnic differences in health (Reijneveld 2010).

Evidence demonstrates that Roma people face serious barriers in access to healthcare. Such barriers include lack of health insurance and other official documentation leading to exclusion of Roma from health services, geographic isolation from quality care, lack of information, language and communication obstacles, direct discrimination, degrading treatment and human rights violations in the provision of care (European Roma Rights Centre 2006; Council of Europe and EUMC 2003). Roma children are particularly affected by a range of barriers in obtaining health services (Rechel et al. 2009).

\section{Better evidence for better interventions}

There is a need to explore further how the specific barriers impact on the use of different types of care in Roma. Available studies suggest that Roma people overuse emergency care and underuse prevention services such as mandatory immunization for children (Fundación Secretariado Gitano 2009). Furthermore, the effects of health 
system reforms on access to healthcare for Roma require systematic and comparative research. A few studies are available from Bulgaria with focus on Roma children (Rechel et al. 2009) and Macedonia (Milevska-Kostova 2010). More research is needed to enable learning from cross-country experience.

Despite their crucial role as primary caregivers in Roma families and mediators between Roma communities and health systems (Open Society Institute 2005), Roma women are often overlooked in health-related research. Dual discrimination (ethnic and gender) against Roma women in the healthcare setting has been documented by researchers (Surdu and Surdu 2006) and NGOs working in Central and East-European countries to advance the health rights of Roma women (European Roma Rights Centre 2006). Systematic research and comparable data are needed to design tailored responses minimizing the effects of specific barriers met by Roma women in accessing to healthcare.

Several programs have been initiated at national and international levels to reduce the Roma health gap. Various measures have been launched under the Decade of Roma Inclusion 2005-2015 and action is also urged under the recently adopted EU Framework for National Roma Integration Strategies up to 2020 (European Commission 2011). Assessing the impact of programs implemented so far and providing evidence-based input for the development of further innovative actions is an upcoming challenge that requires the contribution of the public health research community.

\section{Research on Roma health and access to healthcare: the way forward}

Research on Roma and health is challenging. Such research must be methodologically sound, and findings must be compared to the majority populations. Obstacles to data collection and methodological challenges have been discussed repeatedly (Kósa and Ádány 2007, Hajioff and McKee 2000; Vokó et al. 2009). Often fragmented research is based on rather inadequate samples. Yet, experience has shown that the Roma communities across Europe present cultural differences that have health implications making it difficult to generalize fragmented research (Krumova and Ilieva 2008). Research of Roma health and access to healthcare should take into account such cultural differences.

Last but not least, it is important to pursue research agendas that reflect better the needs of the Roma minority itself. Involvement of Roma people in the design and implementation of such research agendas contribute to a better understanding of their needs. Cooperation with Roma civil society helps in bringing the insider's perspective, reaching out to the most marginalized communities whose health needs require urgent attention but remain overlooked often.

Open Access This article is distributed under the terms of the Creative Commons Attribution Noncommercial License which permits any noncommercial use, distribution, and reproduction in any medium, provided the original author(s) and source are credited.

\section{References}

Council of Europe and EUMC (2003) Breaking the barriers-Romani women and access to public health care. Luxembourg, office for official publications of the European communities

European Commission (2011) Communication from the Commission to the European Parliament, the Council, The European Economic and Social Committee and the Committee of the Regions: An EU Framework for National Roma Integration Strategies up to 2020. COM (2011) 173 final, Brussels, European Commission

European Roma Rights Centre (2006) Ambulance not on the way: the disgrace of health care for Roma in Europe. Budapest, European Roma Rights Centre

Fundación Secretariado Gitano (2009) Health and the Roma community: analysis of the situation in Europe. Madrid, FSG

Hajioff S, McKee M (2000) The health of the Roma people: a review of the published literature. J Epidemiol Community Health 54:864-869

Kolarcik P, Madarasova Geckova A, Orosova O, van Dijk JP, Reijneveld SA (2009) To what extent does socioeconomic status explain differences in health between Roma and non-Roma adolescents in Slovakia? Soc Sci Med 68:1279-1284

Kolarcik P, Madarasova Geckova A, Orosova O, van Dijk JP, Reijneveld SA (2010) Predictors of health-endangering behaviour among Roma and non-Roma adolescents in Slovakia by gender. J Epidemiol Community Health 64:1043-1048

Kósa K, Ádány R (2007) Studying vulnerable populations. lessons from the Roma minority. Epidemiology 18(3):290-299

Krumova T, Ilieva M (2008) The health status of Romani women in Bulgaria. Veliko Turnovo, Centre for Interethnic Dialogue and Tolerance "Amalipe"

Masseria C, Mladovsky P, Hernández-Quevedo C (2010) The socioeconomic determinants of the health status of Roma in comparison with non-Roma in Bulgaria, Hungary and Romania. Eur $\mathbf{J}$ Public Health 20(5):549-554

Milevska-Kostova N (2010) Access to health services for roma: legal, institutional and policy challenges in Macedonia. Paper presented at the third conference on migrant and ethnic minority health in Europe. Pécs, May 28

Mladovsky P (2007) To what extent are Roma disadvantaged in terms of health and access to health care? What policies have been introduced to foster health and social inclusion? Research Note for the European Commission, DG Employment and Social Affairs

Open Society Institute (2005) Mediating Romani health: policy and program opportunities. Open Society Institute, New York

Paulik E, Nagymajtényi L, Easterling D, Rogers T (2011) Smoking behaviour and attitudes of Hungarian Roma and non-Roma population towards tobacco control policies. Int J Public Health 56:485-491

Rechel B, Blackburn CM, Spencer NJ, Rechel B (2009) Access to health care for Roma children in Central and Eastern Europe: findings from a qualitative study in Bulgaria. Int J Equity Health $8: 24$ 
Reijneveld SA (2010) Ethnic differences in health and use of health care: the questions to be answered. Int $\mathrm{J}$ Public Health 55:353-355

Rosicova K, Madarasova Geckova A, Rosic M, Speybroeck N, Groothoff JW, van Dijk JP (2011) Socioeconomic factors, ethnicity and alcohol-related mortality in regions in Slovakia. What might a tree analysis add to our understanding? Health and Place 17:701-709
Surdu L, Surdu M (2006) Broadening the agenda: the status of Romani women in Romania. Open Society Institute, Budapest

Vokó Z, Csépe P, Németh R, Kósa K, Széles G, Ádány R (2009) Does socioeconomic status fully mediate the effect of ethnicity on the health of Roma people in Hungary? J Epidemiol Community Health 63:455-460

Zeman CL, Depken DE, Senchina DS (2003) Roma health issues: a review of the literature and discussion. Ethn and Health 8:223-249 